\title{
A Case of Listeria Rhombencephalitis Mimicking Vertebrobasilar Stroke
}

\author{
Vertebrobaziller Enfarktı Taklit Eden Listeria Rombensefaliti
}

Keywords: Listeria, rhombencephalitis, brainstem, infection, stroke

Anahtar Kelimeler: Listeria, rombensefalit, beyin sapı, enfeksiyon, inme

Dear Editor,

We want to present a patient with rhombencephalitis due to Listeria monocytogenes who was incorrectly diagnosed as having ischemic vertebrobasilar infarct because of diagnostic difficulties and died after progression in a short period of time.

A man aged 49 years was transferred from an external institution to our clinic because he required treatment in intensive care. His medical history revealed pulmonary tuberculosis 5 years previously and oral aphtosis 3 months ago. He presented to the external center approximately a week ago with sudden-onset headache, imbalance, nausea, and vomiting; brain magnetic resonance imaging (MRI) demonstrated hyperintense lesions in T2-weighted images in the right middle cerebellar peduncle and left pontomedullary junction, which were believed to be ischemic in nature. His neurologic examinations revealed progressive diplopia, ataxia, and clouded sensorium, and he was referred due to intensive care unit. At his admission to our clinic he was drowsy, he opened his eyes with verbal stimulation, and cooperated to simple commands; orientation to place, time, and person was diminished. He had anisocoria with wider pupil diameter on the left, limitation of adduction and elevation in the left eye, and gaze palsy in all directions in the right eye. Muscle strength was 4/5 on the right. Subfebrile fever $\left(37.4^{\circ} \mathrm{C}\right.$ ) and tachycardia (pulse rate: $110 / \mathrm{min}$, rhythmic) were detected. Liver and kidney function tests, electrolyte levels, and C-reactive protein were within normal limits, and there was mild leukocytosis (leukocyte: $13200 / \mu \mathrm{L}$, neutrophils: $82 \%$ ). The patient's clinical presentation progressed on the same day. He was opening his eyes after painful stimulus, he had no cooperation and verbal response, total ophthalmoparesis in the left eye, loss of bilateral light and gag reflexes, prominent quadriparesis on the right side and right half of the face, and there were focal seizures involving his right leg and arm.

Repeated brain MRI showed T2A and fluid-attenuated inversion-recovery (FLAIR) hyperintensities in the left thalamic region, mesencephalon, left half of the pons, right brachium pontis, and bulbus. These lesions were thought to be suggestive of brainstem encephalitis or neuro-Behçet's disease. Lumbar puncture was performed and empiric antituberculosis, antiviral, antibacterial, and corticosteroid treatments were initiated. Biochemical tests of the cerebrospinal fluid (CSF) were as follows: protein: $122 \mathrm{mg} /$ $\mathrm{dL}$, (normal: 15-45 mg/dL), Cl: $124 \mathrm{mEq} / \mathrm{L}$ (normal: 118-132 $\mathrm{mEq} / \mathrm{L}$ ), glucose: $52 \mathrm{mg} / \mathrm{dL}$, and simultaneous blood sugar was $166 \mathrm{mg} / \mathrm{dL}$. Direct examination of CSF revealed 50 leukocytes and 3-5 erythrocytes per power field. Fever became more prominent $\left(39^{\circ} \mathrm{C}\right.$ ) on the second day of his admission. The patient was intubated and mechanical ventilator support was initiated because of hypoxemia, hypercapnia, and decreased saturation. Under ceftriaxone, ampicillin, metronidazole, acyclovir, anti-tuberculosis, and corticosteroid treatments, the patient died on the $4^{\text {th }}$ day of admission due to septic shock. Postmortem, bacteriologic

Address for Correspondence/Yazışma Adresi: İlay Hilal Kılıç MD, Ege Univesity Faculty of Medicine, Department of Neurology, İzmir, Turkey Phone: +90 5317191253 E-mail: ilayhilalkilic@hotmail.com

Received/Geliş Tarihi: 17.04.2016 Accepted/Kabul Tarihi: 19.06.2016

${ }^{\circ}$ Copyright 2016 by Turkish Neurological Society

Turkish Journal of Neurology published by Galenos Yayınevi. 
evaluation of CSF revealed Listeria monocytogenes growth that was resistant to ampicillin and sensitive to erythromycin, and gentamycin (Figure 1,2).

As in our case, rhombencephalitis generally follows a biphasic course. At the beginning there may be headache, malaise, high fever, nausea, and vomiting. A few days later, there may be cranial nerve findings, ataxia, tremor and other cerebellar findings, impaired consciousness, seizures, and hemiparesis. Respiratory insufficiency develops in approximately half of all patients. Differential diagnosis of rhombencephalitis includes several infectious and noninfectious diseases (1), but Listeria monocytogenes is the leading infectious cause. Other possible causes include herpes simplex encephalitis involving brain stem and/or cerebellum (2); tuberculosis, toxoplasmosis, cryptococcosis, and other fungal infections; Lyme disease, Epstein-Barr virus, brucellosis, and John Cunningham virus.

Non-infectious causes include multiple sclerosis involving the brainstem and/or cerebellum, sarcoidosis, systemic rheumatologic diseases (Behçet's disease, systemic lupus erythematosus, relapsing polychondritis), lymphoma, and paraneoplastic syndromes.
At first our patient was misdiagnosed as brainstem ischemic infarct and antiplatelet treatment was initiated because he presented with diplopia, ataxia, and nausea; fever and meningeal irritation were absent; and MRI revealed hyperintense T2 and FLAIR lesions in MR imaging consistent with the vertebrobasilar arterial supply area. The patient was referred to our clinic because of his requirement for intensive care. We suspected central nervous system parenchymal involvement due to Behçet's disease and started corticosteroids. We also suspected brainstem encephalitis and started empiric antibiotherapy, but only a week after his symptoms had begun. He died 3 days after the treatment was initiated.

Mild CSF abnormalities also contribute to a delay in diagnosis. The detection rate in culture is approximately $40 \%$ for CSF and $60 \%$ for blood (3). In our case, growth was not detected in the blood culture, and CSF culture results could only be obtained postmortem. Computed tomography may be normal in the acute period and MRI is more sensitive to demonstrate brainstem pathology (3).

In a study involving 62 patients, the mortality rate of Listeria rhombencephalitis was $51 \%$. All untreated patients died and
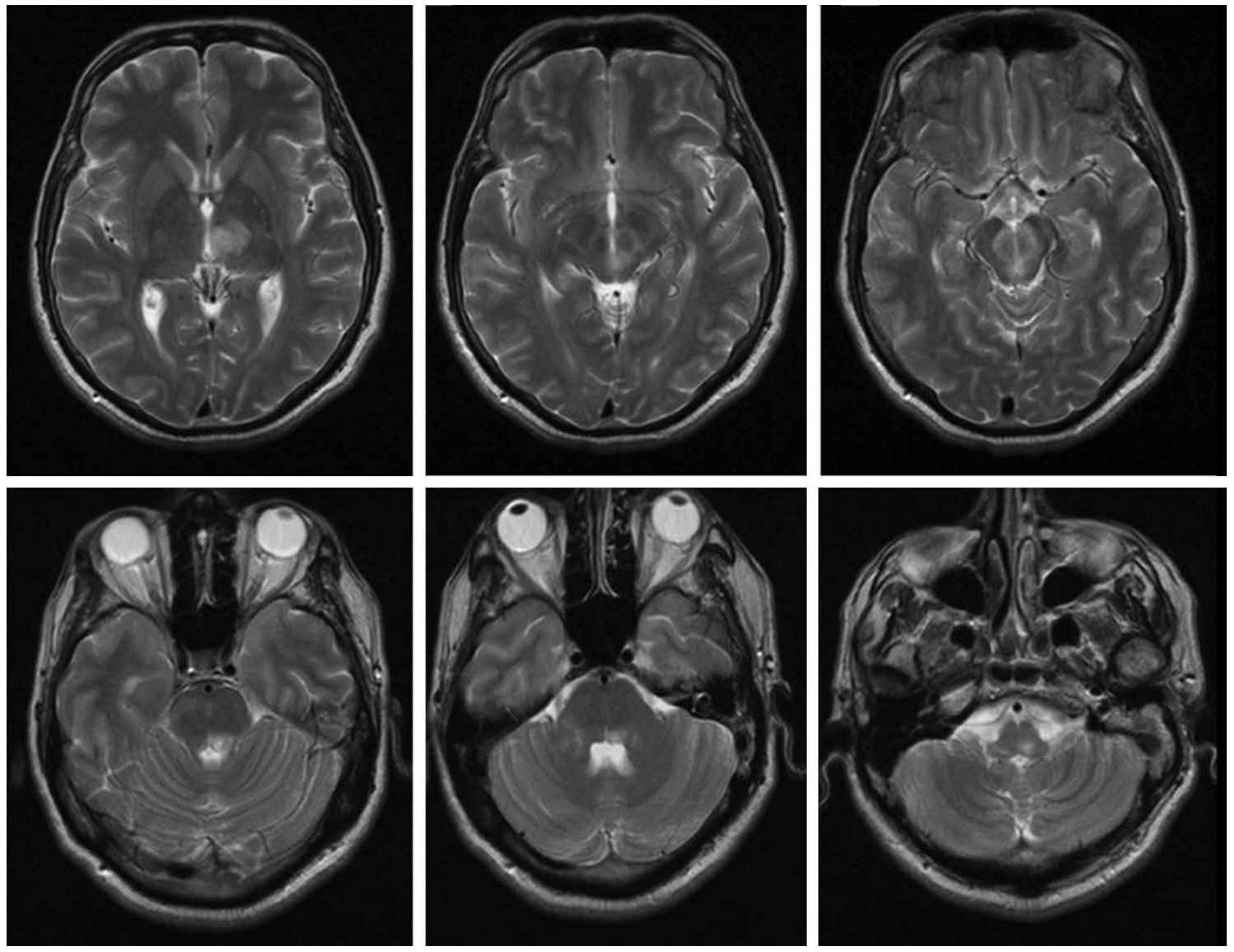

Figure 1. T2-weighted magnetic resonance imaging shows hyperintensities in the left thalamus, mesencephalon, pons, and in the right brachial pontis and bilateral bulbus 

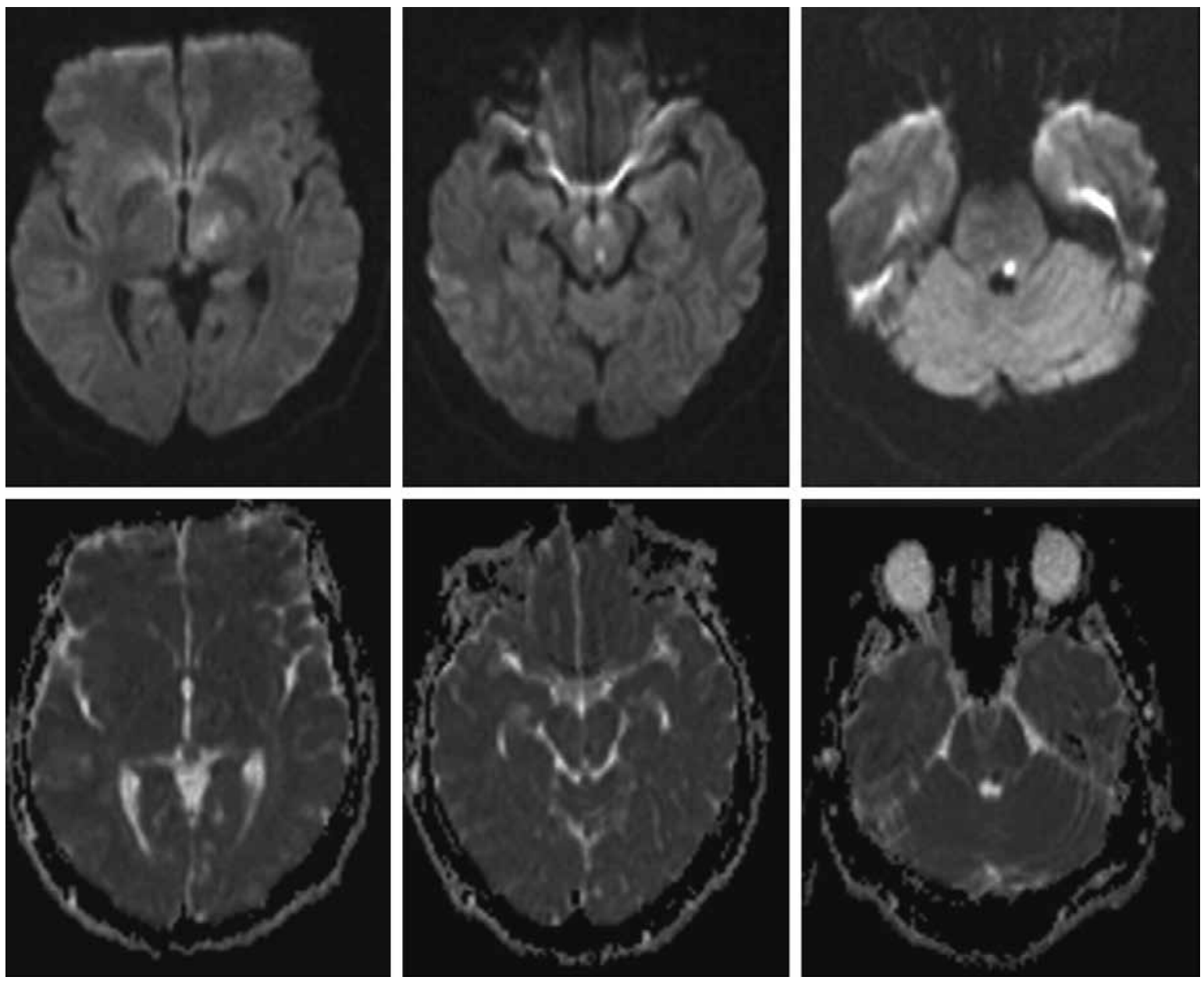

Figure 2. Diffusion-weighted magnetic resonance imaging showed restriction of diffusion in the left thalamus, mesencephalon, and pons consistent with cytotoxic edema

more than $70 \%$ of patients who were treated with antibiotherapy survived; however, neurologic sequelae were detected in $61 \%$ of these patients (3). Therefore, empiric treatment should be started without delay when the diagnosis is suspected.

\section{Ethics}

Peer-review: Internally peer-reviewed.

\section{Authorship Contributions}

Surgical and Medical Practices: Hadiye Şirin, Ayşe Güler, İlay Hilal Kılıç, Concept: Hadiye Şirin, Ayşe Güler, İlay Hilal Kılıç, Design: Hadiye Şirin, Ayşe Güler, İlay Hilal Kılıç, Data Collection or Processing: İlay Hilal Kılıç, Analysis or Interpretation: Ayşe Güler, İlay Hilal Kılıç, Literature Search: İlay Hilal Kılıç, Writing: İlay Hilal Kılıç.
Conflict of Interest: No conflict of interest was declared by the authors.

Financial Disclosure: The authors declared that this study received no financial support.

\section{References}

1. Moragas M, Martinez-Yelamos S, Majos C, Fernandez-Viladrich P, Rubio F, Arbizu T. Rhombencephalitis: a series of 97 patients. Medicine (Baltimore) 2011;90:256-261.

2. Protopsaltis J, Kokkoris S, Brestas PS, Chrysos G, Salvanos L, Samara C, Giannoulis G. Neurolisteriosis mimicking herpes simplex encephalitis in an immunocompromized patient. Scand J Infect Dis 2006;38:825-828.

3. Armstrong RW, Fung PC. Brainstem encephalitis (rhombencephalitis) due to Listeria monocytogenes: case report and review. Clin Infect Dis 1993;16:689702 . 